\title{
PENINGKATKAN KESEJAHTERAAN PETANI MELALUI INOVASI TEKNOLOGI PRODUK TURUNAN KELAPA DALAM DI SULAWESI BARAT
}

\author{
Chairul Muslim dan Valeriana Darwis \\ Peneliti di Pusat Sosial Ekonomi dan Kebijakan Pertanian \\ Sekretariat Jenderal Kementerian Pertanian \\ Kampus Penelitian Pertanian Cimanggu \\ Jl. Tentara Pelajar No. 3 B Bogor \\ Email: chairulmuslimc@gmail.com
}

\begin{abstract}
The development of acreage and production of oil in the nationally decreased $1.17 \%$ and $1.54 \%$ annually in the period of last six years. Coconut productivity in one hectare never reaches 1 ton.The low productivity of coconut in the village of East Mines West Sulawesi province because of old age (30-45 years) and not cultivated optimally (legacy). The purpose writing papers is a condition of the coconut in West Sulawesi and coconut derived products what is normally made by the communities in research and technology are being used to make these derivative products. Next will be given advice what technology should be used by the coconut farmers. Products derived from coconut are made and the technology makes it also unchanged from the first, namely copra, coconut shell charcoal and cooking oil. In order for the coconut farmers' income can be increased then it is advisable for the rejuvenation of coconut. Technological changes in line with recommendations made: (i) copra so that it can increase the water content from $12 \%$ to $7 \%$; (Ii) cooking oil that is produced does not smell and can be more durable (iii) charcoal that produced containing low water content, still flying high oil content, as well as the holding capacity of carbon is also high as desired by some industries
\end{abstract}

Keywords: coconut, derivative products and technologies

\begin{abstract}
Abstrak: perkembangan luas areal dan produksi kelapa dalam secara nasional mengalami penurunan $1,17 \%$ dan $1,54 \%$ setiap tahun dalam kurun waktu enam tahun terakhir. Produktivitas kelapa dalam satu hektar tidak pernah mencapai 1 ton. Rendahnya produktivitas kelapa dalam di Desa Lombong Timur Provinsi Sulawesi Barat karena usianya yang sudah tua (30-45 tahun) dan tidak diusahakan secara optimal (warisan). Tujuan penulisan makalah adalah mengetahui kondisi perkelapaan di Sulawesi Barat dan produk turunan kelapa apa yang biasanya dibuat oleh masyarakat di lokasi penelitian serta teknologi apa yang dipergunakan untuk membuat produk turunan tersebut. Selanjutnya akan diberikan saran teknologi apa yang sebaiknya dipergunakan oleh petani kelapa. Produk turunan dari kelapa yang dibuat dan teknologi membuatnya juga tidak mengalami perubahan dari dahulu, yaitu kopra, arang tempurung dan minyak goreng. Agar pendapatan petani kelapa dapat ditingkatkan maka disarankan adanya peremajaan kelapa. Perubahan teknologi sesuai dengan anjuran membuat : (i) kopra sehingga bisa meningkatkan kadar air dari $12 \%$ menjadi $7 \%$; (ii) minyak goreng yang dihasilkan tidak bau dan bisa lebih tahan lama : (iii) arang yang dihasilkan mengandung kadar air rendah, kandungan minyak terbang masih tinggi, serta daya ikat karbon juga tinggi seperti yang diinginkan oleh beberapa industri.
\end{abstract}

Kata kunci : kelapa dalam, produk turunan dan teknologi 


\section{PENDAHULUAN}

Dalam peringatan Hari Pangan Sedunia yang ke 36 di Boyolali Menteri Pertanian Amran Sulaiman mengingatkan kembali, untuk meningkatkan produktivitas dan swasembada pangan dapat dicapai dengan mengadopsi pertanian modern berbasis teknologi. Sinergi pertanian dan teknologi di Litbang Kementan diwujudkan dalam kegiatan sistem pertanian bioindustri. Dalam sistem pertanian bioindustri selain pengembangan konsep zero waste management, juga pengembangan konsep pertanian berkelanjutan, dengan mengintegrasikan aspek lingkungan dengan sosial ekonomi masyarakat pertanian untuk mempertahankan ekosistem alami lahan pertanian yang sehat, melestarikan kualitas lingkungan, dan melestarikan sumber daya alam. Pertanian berkelanjutan harus dapat memenuhi kriteria keuntungan ekonomi, keuntungan sosial, dan konservasi lingkungan secara berkelanjutan.

Pertanian bioindustri berkelanjutan merupakan solusi pembangunan Indonesia masa depan. Konsep ini dapat dipandang sebagai awal pencanangan pengembangan bioekonomi berbasis pertanian, landasan strategis dalam pembangunan pertanian jangka panjang, dan mainstreaming perspektif bioekonomi di Indonesia. Implementasi konsep bioekonomi melalui pengembangan Sistem Pertanian-Bioindustri Berkelanjutan secara luas namun bertahap. Hendaknya perspektif sistem pertanian-bioindustri berkelanjutan menurut Pantjar Simatupang (2014) meliputi: 1) Usaha pertanian berbasis ekonomi intensif (diversifikasi spasial dan temporal, integrasi tanaman-ternak-ikan), 2) pengolahan seluruh hasil pertanian dalam konsep biomassa-biorefinery, 3) Integrasi usaha pertanian-biodigester-biorefinery.

Ada beberapa komoditi pertanian yang dilaksanakan dalam kegiatan pertanian bioindustri diantaranya adalah kelapa (Cocos nucifera L). Kelapa memiliki peran strategis bagi masyarakat Indonesia, karena kelapa termasuk komoditas sosial, mengingat produknya merupakan salah satu dari sembilan bahan pokok masyarakat dan salah satu sentra produksi kelapa nasional adalah Provinsi Sulawesi Barat.
Meskipun produksi kelapa Indonesia besar, tetapi produk yang dihasilkan dan dijual masih dalam bentuk primer. Di Provinsi Sulawesi Barat produk kelapa berupa kelapa butiran, kopra dan minyak goreng yang diolah secara tradisional, sedangkan limbah berupa tempurung, sabut, dan air kelapa belum dimanfaatkan secara optimal. Produk olahan kelapa seperti kopra dan minyak goreng kualitasnya masih sangat rendah. Hal ini disebabkan penguasaan teknologi pengolahan hasil masih tradisional, dan kurang memperhatikan faktor sanitasi. Disamping itu produk olahan kelapa belum dilakukan secara komersial dan belum memenuhi standar mutu yang dikehendaki pasar. Struktur industri kelapa tersebut menyebabkan nilai tambah yang diperoleh dari proses pengolahan kelapa tidak maksimal dan tidak memberi peluang petani ikut menikmati nilai tambah yang tercipta dalam proses pengolahan hasil kelapa. (Dinas Perkebunan dan Kehutanan Provinsi Sulawesi Barat, 2013).

Dengan uraian diatas maka tulisan ini bertujuan ingin mengetahui kondisi perkelapaan di Sulawesi Barat dan produk turunan kelapa apa yang biasanya dibuat oleh masyarakat di lokasi penelitian serta teknologi apa yang dipergunakan untuk membuat produk turunan tersebut. Selanjutnya akan diberikan saran teknologi apa yang sebaiknya dipergunakan oleh petani kelapa.

\section{METODOLOGI}

Tulisan ini merupakan bagian dari laporan hasil penelitian bioindustri yang dilaksanakan di Provinsi Sulawesi Barat. Tulisan ini mempergunakan data sekunder khususnya pertumbuhan kelapa dalam di Indonesia dan data primer yang diperoleh langsung dari petani kelapa dalam. Survei ke lokasi penelitian dilaksanakan pada minggu pertama bulan September 2016. Pemilihan lokasi penelitian berdasarkan daerah sentra produksi kelapa dalam di Provinsi Sulawesi Barat, dengan kriteria tersebut maka lokasi yang terpilih adalah Desa Lombong Timur.

Pengumpulan data primer dilakukan dengan : (i) sistem FGD (Focus Group Discussion) yang dihadiri oleh 10 petani kelapa, 2 orang pedagang, masing-masing 1 orang PPL dan aparat desa, serta 2 orang 
peneliti dari BPTP Sulbar. Fokus FGD yang dilakukan menitikberatkan pada ragam produk turunan kelapa dalam serta teknologi yang dipergunakan oleh petani setempat. (ii) mendatangi dan mewawancari petani kelapa yang mengolah kelapa menjadi produk turunan seperti kopra dan arang tempurung. Wawancara ke petani pengolah lebih menitik beratkan pada proses pembuatan produk turunan. Data yang sudah terkumpul kemudian dianalisis dengan mempergunakan metode deskriptif dan ditampilkan dalam bentuk tabel serta gambar.

\section{HASIL DAN PEMBAHASAN}

\section{Potret Kelapa Dalam Nasional dan Provinsi Sulawesi Barat}

Tanaman kelapa merupakan salah satu aset bangsa Indonesia, karena kelapa mempunyai peranan sosial, budaya dan ekonomi. Selain itu tanaman kelapa juga merupakan salah satu tanaman yang seluruh bagiannya dapat dimanfaatkan. Tanaman kelapa tersebar di seluruh Indonesia dengan pulau yang terluas adalah Pulau Sumatera (34,5\%), kemudian diikuti Pulau Jawa $(23,2 \%)$, Sulawesi $(19,6 \%)$, Bali, NTB dan NTT (8\%), Kalimantan 7,2\%, Maluku dan Papua (7,5\%).

Salah satu jenis kelapa yang diusahakan oleh petani adalah kelapa dalam. Perkembangan luas areal, produksi dan produktivitas kelapa dalam kurun waktu antara tahun 2011 sampai tahun 2016 mengalami pertumbuhan yang kurang bagus. Dalam masa 6 tahun tersebut pertumbuhan kelapa mengalami penurunan rata-rata 1,17 persen pertahun. Hal yang sama juga terjadi pada produksi yang mengalami penurunan rata-rata 1,55 persen pertahun. Sementara produktivitas perhektar kelapa dalam tidak pernah sampai 1 ton perhektar. Menurut Budi. S (2016) rendahnya produktivitas kelapa dalam disebabkan oleh : keragaman genetik kelapa masih tinggi, tanaman kelapa dalam kebanyakan sudah tua, penebangan pohon kelapa dalam untuk bahan bangunan dan terjadinya alih fungsi pemanfaatan lahan untuk pemukiman.

Kalau dilihat dari segi kepemilikan kelapa dalam paling banyak dimiliki dan diusahakan oleh petani rakyat. Pada tahun 2016 dari total luas areal kelapa dalam 3.444.349 ha, 3.421.018 ha atau 99.32 persen dimiliki oleh rakyat dan sisanya 0,56 persen (19.392 ha) dimiliki oleh swasta dan 0,11 persen $(3,939$ ha) dimiliki oleh negara (Tabel 1). Kepemilikan lahan kelapa dalam baik di tingkat rakyat, swasta maupun negara mengalami penurunan selama 6 tahun terakhir. Pada tahun 2011 luas areal kelapa dalam milik rakyat 3.632 .483 ha dan turun sebanyak 210.465 ha. Dalam masa yang sama luas areal kelapa dalam yang dikelola swasta turun seluas 623 ha dan luas areal kelapa dalam yang dikelola swasta negara turun seluas 354 ha.

Tabel 1. Perkembangan Luas areal, Produksi dan Produktivitas Kelapa Dalam

\begin{tabular}{|c|c|c|c|c|c|c|c|}
\hline Kepemilikan & 2011 & 2012 & 2013 & 2014 & 2015 & 2016 & Pertumbuhan \\
\hline Luas areal $(\mathrm{Ha})$ & 3655791 & 3674966 & 3546907 & 3526282 & 3516718 & 3444349 & $(-1,17)$ \\
\hline Rakyat & 3631483 & 3649928 & 3523020 & 3502792 & 3493714 & 3421018 & $(-1,18)$ \\
\hline Negara & 4293 & 4622 & 4079 & 3972 & 3887 & 3939 & $(-1,50)$ \\
\hline Swasta & 20015 & 20416 & 19808 & 19518 & 19117 & 19392 & $(-0,61)$ \\
\hline Produksi (Ton) & 3064875 & 3065608 & 2951401 & 2931811 & 2926414 & 2833808 & $(-1,54)$ \\
\hline Rakyat & 3048650 & 3050596 & 2934471 & 2915038 & 2909974 & 2817200 & $(-1,55)$ \\
\hline Negara & 3107 & 1858 & 2927 & 2896 & 2862 & 2725 & 2,06 \\
\hline Swasta & 13118 & 13154 & 14003 & 13877 & 13578 & 13883 & 1,18 \\
\hline Produktivitas ( Ton/Ha) & 0,84 & 0,83 & 0,83 & 0,83 & 0,84 & 0,82 & $-0,47$ \\
\hline Rakyat & 0,84 & 0,84 & 0,83 & 0,83 & 0,83 & 0,82 & $-0,48$ \\
\hline Negara & 0,72 & 0,4 & 0,72 & 0,73 & 0,74 & 0,69 & 6,31 \\
\hline Swasta & 0,66 & 0,64 & 0,71 &, 71 & 0,71 & 0,72 & 1,86 \\
\hline
\end{tabular}

Sumber : Direktorat Jenderal Perkebunan 
Tabel 2. Perkembangan Luas Panen, Produksi Dan Produktivitas Kelapa Dalam Menurut Kabupaten Di Provinsi Sulawesi Barat

\begin{tabular}{|c|c|c|c|c|c|c|c|c|c|c|c|c|c|c|c|}
\hline \multirow[b]{2}{*}{ tahun } & \multicolumn{3}{|c|}{ Majene } & \multicolumn{3}{|c|}{ Polewali Mandar } & \multicolumn{3}{|c|}{ Mamasa } & \multicolumn{3}{|c|}{ Mamuju } & \multicolumn{3}{|c|}{ Mamuju Utara } \\
\hline & 1 & 2 & 3 & 1 & 2 & 3 & 1 & 2 & 3 & 1 & 2 & 3 & 1 & 2 & 3 \\
\hline 2010 & 9.118 & 9.123 & 1,00 & 22.291 & 19.505 & 0,88 & 76 & 17 & 0,22 & 7376 & 3.177 & 0,43 & 10726 & 8933 & 0,83 \\
\hline 2012 & 9.137 & 10.3 & 1,13 & 20.321 & 18.45 & 0,91 & 147 & 59 & 0,40 & 7.377 & 5.362 & 0,73 & 10552 & 9474 & 0,90 \\
\hline 2013 & 6.767 & 7.109 & 1,05 & 15.697 & 18.338 & 1,17 & 24 & 64 & 0,00 & 4.733 & 4.731 & 1,00 & 6953 & 8516 & 1,22 \\
\hline
\end{tabular}

Sumber : Dinas Perkebunan Sulawesi Barat

Ket : 1 = luas panen (ha) $; 2=$ produksi (ton) $; 3$ produktivitas (ton/ha)

Provinsi Sulawesi Barat merupakan salah satu provinsi sentra penghasil kelapa dalam di Pulau Sulawesi. Kondisi perkembangan luas areal dan produksi kelapa dalam mengikuti perkembagan luas areal dan produksi kelapa dalam nasional. Dimana dalam masa lima tahun terakhir (2010-2014) luas areal kelapa dalam mengalami penurunan dari 49.587 ha pada tahun 2010 menjadi 41.738 ha pada tahun 2014. Hal yang sama juga terjadi pada produksi yaitu mengalami penurunan dari 40.755 ton pada tahun 2010 menjadi 36.120 ton pada tahun 2014.

Kalau dilihat perkabupaten hanya Kabupaten Mamasa yang mengalami penambahan areal luas panen dari 76 ha pada tahun 2010 menjadi 131 ha pada tahun 2014 (Tabel 2).

\section{Potret Desa Lombong Timur dan Manfaat Kelapa Dalam}

Desa Lombong Timur merupakan desa pemekaran dari Desa Lombong yang secara resmi menjadi desa pada tahun 2010. Secara keseluruhan desa ini berdiri dilahan seluas 3.42 $\mathrm{km}^{2}$ dan dapat ditempuh dari ibu kota provinsi Sulawesi Barat sekitar $\pm 1,5$ jam ( $40 \mathrm{~km}$ ). Desa Lombang Timur mempunyai batas wilayah sebagai berikut : (i) Sebelah Utara berbatasan dengan Desa Lombang Kecamatan Malunda ; (ii) Sebelah Selatan berbatasan dengan Desa Kabiraan Kecamatan Ulumanda ; (iii) Sebelah Timur berbatasan dengan Desa Ulumanda Kecamatan Ulumanda ; (iv) Sebelah Barat berbatasan dengan Desa Lombang Kecamatan Malunda.

Pertanian yang dominan diusahakan oleh masyarakat desa adalah perkebunan, khususnya tanaman kelapa dalam. Luas areal kelapa dalam di dalam desa juga mengalami pasang surut. Pada tahun 1990 luas lahan kebun kelapa dalam sekitar 300 ha, kemudian meningkat menjadi 400 ha antara tahun tahun 2000 sampai tahun 2015. Pada tahun 2016 jumlahnya berkurang 11 hektar, karena dialih fungsikan untuk kegiatan pencetakan sawah. Dari segi kepemilikan umumnya masyarakat memiliki lahan kelapa dalam rata-rata seluas 1 hektar perkepala keluarga dengan umur kelapa dalam berkisar antara 30 - 45 tahun.

Pohon kelapa banyak sekali memberikan manfaat, mulai dari daun, batang dan buahnya. Dari buah kelapa sendiri airnya dapat digunakan antara lain untuk aneka minuman, kecap, cuka, nata decoco. Daging buahnya bisa untuk kopra dan sabut kelapanya bisa dimanfaatkan sebagai bahan baku untuk industri lainnya. Lebih lengkap manfaat buah kelapa dapat dilihat pada gambar tentang pohon industri kelapa sebagai berikut pada Gambar 1 .

Di lokasi penelitian kelapa dalam masih dimanfaatkan secara terbatas dalam bentuk : menjual secara langsung buah kelapa untuk dikonsumsi, dijadikan kopra, dibuat minyak kelapa dan tempurungnya dijadikan arang. Teknologi untuk membuat produk turunan tersebut masih tradisi turun temurun.

Petani kelapa di desa ini umumnya memanen/memetik kelapa 3 sampai 4 kali dalam setahun. Pohon kelapa dapat ditanami sejumlah 200 batang dalam satu hektar dan dalam satu kali petik bisa mencapai 2.500 butir perhektar. Kelapa tersebut ada yang dijual langsung di dalam desa dengan harga perbutir Rp. 1.500, ada juga yang menjual di pinggir jalan dengan harga Rp. 2.500 perbutir. Tetapi yang menjadi permasalahan tidak ada yang membeli dalam jumlah yang besar. 


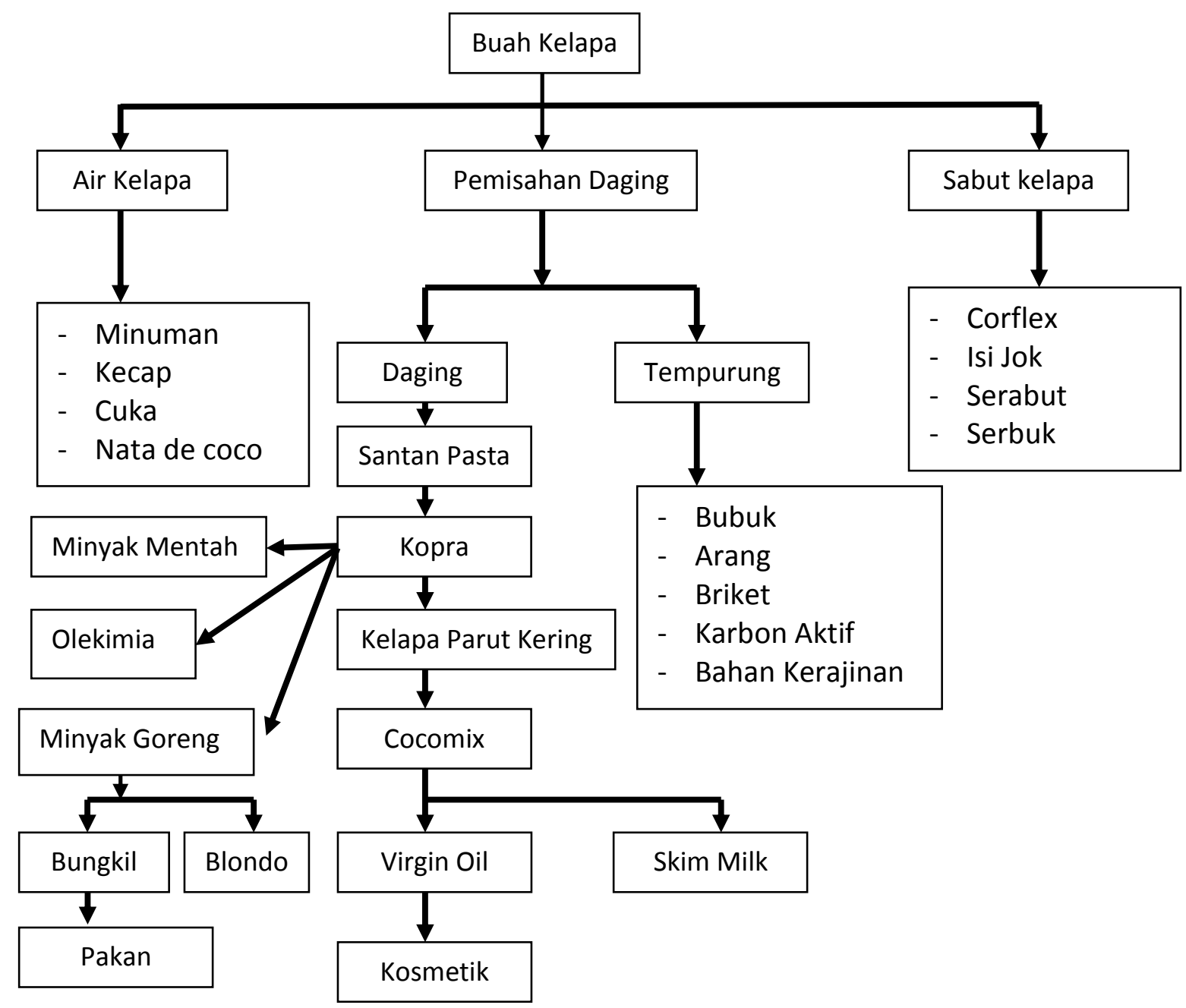

Gambar 1. Pohon Industri Kelapa

Umumnya petani lebih senang menjual kelapa dalam bentuk kopra, dengan cara mencungkil daging kelapa kemudian dibakar selama 2 hari (masih mempergunakan cara tradisional). Untuk menghasilkan $1 \mathrm{~kg}$ kopra kering dibutuhkan 5 butir kelapa dan 1 kilogram kelapa di jual seharga Rp. 10.000 di lokasi petani. Kopra kering tersebut di bawa ke Makassar dan dijual dengan harga Rp. 14.000 perkilogramnya.

Produk lainnya dari buah kelapa adalah minyak kelapa atau dalam bahasa daerah masyarakat lebih mengenal dengan sebutan minyak mandar. Cara pembuatan minyak mandar adalah santan kelapa dimasak sekitar 5 sampai 6 jam, tergantung kapasitas santan yang dimasak. 50 butir kelapa akan menghasilkan 8 liter minyak mandar. Bila di jual perkilonya bisa laku seharga Rp. 18.000. Umumnya minyak mandar dipergunakan untuk konsumsi sendiri tidak untuk dikomersilkan. Oleh karena itu petani membuat minyak mandar, minimal dalam satu bulan satu kali.

Manfaat lain dari kelapa adalah batok atau tempurung kelapa yang bisa dipergunakan sebagai bahan baku industri arang tempurung. Petani biasanya menjual batok atau tempurung kelapa ke pedagang arang tempurung dalam bentuk kemasan karung. Dalam satu karung dihargai pedagang sebesar Rp. 20.000 dan satu karung tempurung beratnya sekitar $50 \mathrm{~kg}$. Batok kelapa yang dibakar menjadi arang tempurung dijual pedagang ke konsumen dengan harga perkilogramnya sebesar Rp. 3.300. Di dalam Desa pedagang atau penampung arang batok kelapa ada 5 orang, yang hasil pembelian dari petani langsung dikirim ke makasar. 
Anjuran Adopsi Teknologi Produk Turunan Sebagian besar industri pengolahan kelapa menerapkan teknologi tingkat sedang, penanganan kurang efisien, fasilitas terbatas, kurang tenaga terampil dan biaya produksi tinggi sehingga produk yang dihasilkan tidak kompetitif (Ibrahim, 1989). Menurut ,Soebiapradja (1991) pengembangan industri kelapa di masa mendatang perlu mempertimbangkan : (a) prinsip pengolahan yang mudah dilakukan petani dan produk yang dihasilkan memenuhi standar mutu, (b) diperlukan industri yang menggunakan teknologi maju yang dioperasikan berkesinambungan agar produk yang dihasilkan kompetitif terutama di pasar ekspor, dan (c) meningkatkan efisiensi pengolahan dan pengembangan produk bernilai ekonomi cukup tinggi dan mempunyai pasaran luas. Transformasi pertanian sebaiknya dilakukan secara gradual. Pengetahuan tradisional dan kearifan lokal harus diperhatikan dalam memperbaharui teknologi di tingkat petani. Keterpaduan antara pengalaman, kearifan lokal dan teknologi maju akan menghasilkan teknologi maju tepat guna.

Pada umumnya usahatani kelapa dalam di Provinsi Sulawesi Barat dilakukan masih tradisional tanpa pemeliharaan yang intensif sehingga produk yang dihasilkan belum optimal. Demikian juga pengolahan hasil di tingkat petani atau skala pedesaan, termasuk sebagian besar terbatas pada penanganan daging buah dengan produk yang dihasilkan berupa kelapa butiran, kopra dan minyak kelentik. Komponen hasil lainnya yang bernilai ekonomi seperti sabut, tempurung, dan air kelapa masih kurang mendapat perhatian. Teknologi proses pengolahan minyak kelapa, yang berkembang dimasyarakat selama ini masih sangat terbatas, sehingga kualitasnya perlu ditingkatkan.

Berdasarkan sistem pengolahan, pengolahan kelapa dibagi dalam dua sistem, yaitu parsial dan terpadu. Pengolahan parsial adalah cara pengolahan dengan memanfaatkan sebagian atau salah satu dari komponen hasil kelapa yang terdiri dari sabut, tempurung, daging, dan air kelapa dalam satu unit proses. Pengolahan terpadu adalah cara pengolahan yang mendayagunakan seluruh komponen hasil kelapa pada beberapa unit proses dalam satu unit pengolahan (Grimwood, 1975 dalam
Balitka, 2004). Pengolahan kelapa terpadu akan meningkatkan nilai tambah komoditas kelapa dan peningkatan harga kelapa butiran yang akan diterima petani. Pengembangan pengolahan terpadu akan lebih menguntungkan dibandingkan dengan pengolahan parsial antara lain karena: (a) peningkatan efisiensi bahan baku, (b) perluasan lapangan kerja, (c) peningkatan pendapatan petani, dan (d) pemantapan keterkaitan antar sektor industri, pertanian, jasa dan sektor lainnya (Mulyadi, et. al (1989) dalam Balitka (2004).

\section{Pembuatan Kopra}

Kopra adalah daging buah kelapa yang dikeringkan. Kopra merupakan salah satu produk turunan kelapa yang sangat penting, karena merupakan bahan baku pembuatan minyak kelapa yang digunakan dalam kebutuhan sehari-hari dan juga digunakan sebagai obat tradisional dan kecantikan. Kopra juga mempunyai daya jual yang lebih tinggi dari pada kelapa mentah. Daging kelapa didapat dengan mencungkil dari tempurung secara manual atau memakai mesin cungkil kopra kemudian dikeringkan dengan bantuan sinar matahari atau panas buatan.

Sementara petani kelapa di Desa Lombong Timur membuat kopra masih mempergunakan teknologi yang sangat sederhana atau masih mempergunakan kebiasaan turun temurun. Adapun cara yang biasa dilakukan dalam pembuatan kopra dimulai dengan memanen kelapa dengan cara memanjat atau menunggu jatuh sendiri. Kelapa hasil panen dikupas/dicukil untuk diambil dagingnya kemudian daging tersebut dijemur diatas terpal. Pada musim kemarau biasanya dijemur dihalaman samping atau depan rumah selama 2 sampai 3 hari. Dengan menjemur seperti itu menjadikan kopra terkontaminasi kotoran seperti debu sehingga menurunkan kualitas kopra itu sendiri.

Selain dijemur pembuatan kopra bisa dilakukan dengan cara pembakaran. Tempat pembakaran daging kelapa di dalam desa bisa dilakukan ditempat yang sudah semuanya dibeton (permanen). Bisa juga dibakar ditempat yang semi permanen, hanya temboknya yang disemen setinggi 1 meter sementara tutupnya pakai kawat bronjong. Bisa juga dibakar di tempat sederhana yang hanya mempergunakan kawat bronjong. Walaupun tempat pembakaran 
bisa berbeda beda tetapi untuk bahan bakarnya mempergunakan bahan yang sama, yaitu sabut kelapa.

Teknik membuat kopra yang biasa digunakan petani tidak bisa mengurangi kadar air dan kadar air yang dihasilkan dengan cara tradisional tersebut berkisar antara 11-12 persen. Kopra yang baik, sebaiknya hanya memiliki kandungan air $6 \%-7 \%$ agar tidak mudah terserang organisme pengganggu. Serangan tersebut mudah terjadi jika kadar air dalam kopra tinggi. Bagi pedagang kadar air ini dipergunakan untuk menjatuh harga jual kopra. Agar bisa membantu petani dalam menambah pendapatan hasil menjual kopra, maka cara pengolahan kopra di petani harus dirubah.

Perubahan ini dimulai pada kegiatan mencungkil daging kelapa dengan mempergunakan mesin khusus mencungkil daging kelapa. Daging kelapa tersebut kemudian dijemur dengan cara : (i) pengeringan dengan sinar matahari, penjemuran sebaiknya jangan 2-3 hari tetapi antara 5 sampai 7 hari. (ii) Pengeringan dengan tudung plastik, Modifikasi dari penjemuran sinar matahari, tetapi memanfaatkan tudung plastik, kopra dijemur dalam areal plastik. Panas yang masuk ke dalam areal plastik akan bertahan lama sehingga penjemuran bisa lebih cepat dari penjemuran biasa. Teknik penjemuran ini lebih baik dari cara penjemuran matahari langsung. (iii) Pengeringan dengan pengasapan, Cara ini adalah teknik yang banyak berkembang di petani kopra. Daging Kelapa dimasukkan ke dalam para-para tungku pengasapan dengan membakar sabut kelapa atau tempurung dibawahnya. Teknik ini membutuhkan waktu kurang lebih 3 hari. (iv) Pengeringan menggunakan oven, Teknik pengeringan kopra ini adalah yang terbaik untuk menghasilkan kopra. Teknik yang dipakai adalah model Lade oven. Prosesnya adalah kelapa basah disusun dalam lemari oven yang telah tersedia, kemudian dipanasi dalam kondisi tertutup; ke dalam ruangan ini dialirkan panas dengan suhu 40 derajat Celcius sampai 80 derajat Celcius. Panas dihasilkan dari pembakaran biomassa yang menghasilkan asap dan panas, kemudian dialirkan oleh blower untuk mengaliri oven pengering kopra.

\section{Minyak goreng}

Hasil pemasakan dari minyak kelapa adalah minyak kelapa yang disebut oleh masyarakat setempat minyak mandar. Cara pembuatan minyak kelapa adalah santan kelapa dimasak sekitar 5-6 jam tergantung kapasitas santan yang dimasak. Bahannya adalah 50 butir kelapa dalam akan menghasilkan 8 liter minyak kelapa. yang membuat minyak goreng hanya untuk konsumsi rumahtangga, belum bersifat komersial, dan mengusahakannya juga relatif sedikit sekitar 10 persen terhadap total petani kebun kelapa. Adapun pembuatan minyak goreng hanya satu bulan sekali.

Proses pengolahan minyak kelapa dilakukan dengan cara pemanasan langsung dengan suhu tinggi. Cara ini menghasilkan minyak kelapa kualitas rendah, karena kandungan air dan asam lemak bebas tinggi yakni masing-masing $0.37 \%$ dan $5.37 \%$, sehingga minyak kelapa lebih cepat menjadi tengik, dengan warna kecoklatan dan daya simpan menjadi lebih pendek (sekitar 35 hari). Untuk menghilangkan bau tengik, minyak menjadi tahan lama dan mengurangi bau khas minyak kampung dengan cara : minyak dipanaskan sampai suhu 70-90 C, masukkan larutan $\mathrm{NaOH} 4 \mathrm{M}$ ke dalam minyak, aduk hingga mengeluarkan busa dan terakhir disaring.

Kelapa dengan kualitas rendah berpeluang untuk dijadikan minyak oleh petani dengan teknologi sederhana yaitu memisahkan bakal minyak (krim dan skim) dengan air melalui penambahan emzim bromelin hanya butuh waktu +3 jam, sehingga mutu minyak goreng yang dihasilkan relatif baik dan tidak tengik. Dengan pemakaian enzim bromelin (sari buah nenas $50 \mathrm{ml} / \mathrm{kg}$ parutan kelapa), bakal minyak(skim dan krim) yang ada pada larutan santan dapat dipisahkan dari air dalam waktu yang reltif pendek (+ 3 jam). Untuk mendapatkan minyak kita hanya memanaskan skim dan krim dalam waktu yang relatif pendek $(+1,5$ jam $)$.

Metoda pembuatannya sebagai berikut: pilih kelapa yang tua dan segar, kemudian aging kelapa diparut, timbang sebanyak $8 \mathrm{~kg}$ kelapa parut, tambahkan 16 liter air dan diperas hingga keluar santannya, siapkan nenas yang sudah matang dikupas kulitnya dan dibuang matanya, parutlah nenas hingga terbentuk 
Tabel 3. Metode Pembakaran Batok Kelapa Menjadi Arang Tempurung

\begin{tabular}{cll}
\hline Metode & \multicolumn{1}{c}{ Keuntungan } & \multicolumn{1}{c}{ Kelemahan } \\
\hline Mempergunakan Drum & $\begin{array}{l}\text { Lebih bersih tidak ada } \\
\text { campuran batu dan tanah. }\end{array}$ & $\begin{array}{l}\text { Waktu pembakaran lebih lama. } \\
\text { Kekuatan drum 2 sd 3 tahun. }\end{array}$ \\
& $\begin{array}{l}\text { Waktu dingin lebih cepat. } \\
\text { Kapasitas tempurung yang } \\
\text { dibakar lebih banyak. }\end{array}$ & $\begin{array}{l}\text { Kapasitas tempurung yang dibakar terbatas. } \\
\text { Berisko pada saat pembakaran dimusim hujan. } \\
\text { Kualitas kurang baik, karena tercampur dengan } \\
\text { Waktu pembakaran lebih } \\
\text { batu atau tanah. }\end{array}$ \\
& cepat. & Waktu dingin lebih lama, sehingga mengangkat \\
& tempurung dari lobang membutuhkan waktu. \\
\hline
\end{tabular}

parutan nenas, kemudian diperas dengan kain saring (tanpa penambahan air) hingga diperoleh sari buah nenas, ambahkan kedalam santan dan diaduk hingga rata, asukkan ke dalam botol aqua yang punya kran pembuang air, biarkan selama lebih kurang 3 jam hingga air dan bakal minyak (krim dan skim), buang airnya perlahan-lahan dengan cara membuka kran, sisa santan/bakal minyak (krim dan skim) kemudian dimasak dalam kuali dengan memakai tungku anglo (hemat bahan bakar kayu) sampai terbentuk minyak,minyak yang didapat kemudian disaring dengan kain saring 2-3 kali.

\section{Industri arang tempurung/ batok kelapa}

Batok kelapa atau tempurung bisa dijadikan arang dengan mempergunakan dua metode, yaitu dengan cara dibakar dengan mempergunakan drum aspal atau dibakar dengan cara membuat lubang tanah sedalam 1 meter. Cara membuat dengan menggunakan drum aspal antara lain dimulai dari menyiapkan drum bekas yang telah dilubangi bagian bawahnya sebanyak 8 buah lubang. Susunlah tempurung (batok) kelapa ke dalam drum tadi kira-kira $1 / 4$ bagian. Setelah tersusun kemudian arang dibakar sampai menyala. Setelah tempurung (batok) kelapa menyala semua, masukkan kembali tempurung (batok) kelapa $1 / 4$ bagian lagi dan seterusnya hingga penuh. Setelah terbakar semua, kemudian tutup dengan plat besi yang dilapisi dengan tanah liat.

Pembuatan dengan menggunakan lubang dimulai dengan menyiapkan tempurung kelapa yang sudah kering. Membuat lubang pada tanah yang kering dengan ukuran kedalaman $1-2$ meter dan panjang $75-100 \mathrm{~cm}$ dan lebar $75-$ $100 \mathrm{~cm}$. Pada dasar lubang digunakan batu bata sebagai alas lubang agar api tahan lama. Pada dasar lubang susunlah kayu kering, lalu bakar.
Setelah api agak besar masukkan tumpurung kelapa (batok kelapa) yang telah bersih dari sabut kira-kira $1 / 4$ bagian lubang. Jika tempurung (batok) kelapa sudah terbakar semua, kemudian masukkan tempurung lagi $1 / 4$ bagian dan seterusnya sampai penuh. Setelah tempurung terbakar semua, permukaan lubang cepat ditutup dengan kayu, pelepah pisang atau tanah bekas galian.

Di Desa Lombong Timur petani yang mengolah tempurung/batok kelapa ada sekitar 4 orang (pembakaran dengan drum) dan 2 orang tempat pembakaran dengan tanah. Kelemahan dan keuntungan dari dua metode ini dapat dilihat pada tabel 3 dibawah ini.

Cara membuat arang secara tradisional pada umumnya tidak menghasilkan arang yang berkualitas. Kualitas arang yang diinginkan oleh industri adalah arang yang memiliki kadar air rendah, kandungan minyak terbang masih tinggi, serta daya ikat karbon juga tinggi. Arang seperti itu banyak diminati antara lain oleh : industri pengolahan makanan, pengolahan air bersih, sistem filterisasi air pada kolam koi, industri baterai kering, dan industri kosmetik.

Cara membuat arang dengan mempersiapkan drum berkapasitas 200 liter. Supaya bisa menghasilkan arang berkualitas tinggi, drum ini perlu dimodifikasi. Drum dibagi menjadi 4 bagian:

1. bagian bawah dibuat terbuka,

2. bagian atasnya terutup, tapi bisa dibuka.

3. bagian cerobong, dan

4. lubang-lubang udara di badan drum.

Untuk bagian cerobong, buat lubang berdiameter $10 \mathrm{~cm}$ di bagian atas drum yang tertutup. Pasangkan cerobong setinggi $30 \mathrm{~cm}$ pada lubang tersebut. Bahan untuk membuat cerobong ini bisa dari seng, aluminum, atau bahan-bahan logam lainnya. Untuk bagian 
tubuh drum, buat 3 lubang yang dibuat berbaris mengelilingi drum. Tiap baris terdiri dari 4 lubang yang berdiameter $13 \mathrm{~mm}$. Jarak antar baris dibuat sepanjang $30 \mathrm{~cm}$.

Setelah alat pembakaran arang tempurung kelapa telah siap, saatnya mulai membakar bahan bakunya, yaitu batok kelapa. Masukkan batok kelapa ke dalam drum, lalu dimulai pembakaran, buka semua lubang-lubang yang ada di badan drum, tutup bagian atasnya, biarkan sampai membara, tapi tidak sampai timbul api. Asap akan keluar melalui cerobong asap selama pembakaran berlangsung. Biarkan proses pendinginan berlangsung secara alami. Jangan sekali-kali memadamkan bara api dengan air karena akan menghasilkan arang yang tak matang atau cacat. Setelah pendinginan selesai, keesokannya dibongkar dan hasilnya berupa arang yang hitam legam.

\section{KESIMPULAN DAN SARAN}

\section{Kesimpulan}

Umumnya kelapa dalam masih dimanfaatkan secara terbatas dalam bentuk kelapa segar, dan masih sebagian kecil petani yang melakukan pengolahan seperti dijadikan kopra, dibuat minyak kelapa dan tempurung kelapa dijadikan arang. Pengolah kelapa dalam dalam bentuk kopra, yakni dengan cara mencungkil daging kelapa kemudian dibakar.

Produk lainnya dari buah kelapa adalah minyak kelapa atau dalam bahasa daerah masyarakat lebih mengenal dengan sebutan minyak mandar. Umumnya minyak mandar dipergunakan untuk konsumsi sendiri tidak untuk dikomersilkan. Oleh karena itu petani membuat minyak mandar, minimal dalam satu bulan satu kali.

Manfaat lain dari kelapa adalah batok atau tempurung kelapa yang bisa dipergunakan sebagai bahan baku industri arang tempurung. Petani biasanya menjual batok atau tempurung kelapa ke pedagang arang tempurung dalam bentuk kemasan karung. Dalam satu karung dihargai pedagang sebesar Rp. 20.000 dan satu karung tempurung beratnya sekitar $50 \mathrm{~kg}$. Batok kelapa yang dibakar menjadi arang tempurung dijual pedagang ke konsumen dengan harga perkilogramnya sebesar Rp. 3.300. Di dalam Desa pedagang atau penampung arang batok kelapa ada 5 orang, yang hasil pembelian dari petani langsung dikirim ke makasar.

\section{Saran}

Agar pendapatan petani kelapa dalam di Desa Lombong Timur bisa ditingkatkan, maka disarankan adanya peremajaan kelapa dalam. Penerapan program peremajaan tanaman kelapa diharapkan dapat terus menjamin mendapatan petani pemilik lahan, selama kegiatan peremajaan berlangsung. Metode peremajaan yang disarankan adalah Metode Tebang Bertahap. Dalam metode ini penebangan dilakukan secara bertahap sebesar 20\% pertahun. Metode ini tidak menggangu pertumbuhan tanaman pengganti dan merupakan alternatif yang paling tepat untuk dterapkan ditinjau dari segi agronomis dan pendapatan petani.

Teknologi membuat kopra mengadopsi teknologi anjuran sehingga kadar air yang biasanya 11 sampai 12 persen bisa ditingkat menjadi 7 persen. Teknologi membuat minyak goreng sesuai dengan anjuran sehingga minyak goreng yang dihasilkan tidak bau dan bisa lebih tahan lama. Pembuatan arang juga mempergunakan teknologi yang bisa menghasilkan arang kadar air rendah, kandungan minyak terbang masih tinggi, serta daya ikat karbon juga tinggi seperti yang diingikan oleh beberapa industri.

\section{DAFTAR PUSTAKA}

BALITKA, 2004. Pascapanen Kelapa. Monograf. Balai Penelitian Kelapa dan Palma Lain Manado, C.V. Kunci BerkatManado. 116 hal.

Budi Santoso (2016). Pengembangan Kelapa Dalam di Sumatera Barat. Warta Penelitian dan Pengembangan Tanaman Industri, Vol 22 No 2. Agustus 2016. Hal 17-19.

Dinas Perkebunan Provinsi Sulawesi Barat. 2013. Profil Potensi Pengolahan Hasil Komoditas Unggulan Perkebunan Provinsi Sulawesi Barat

Ibrahim, M.A. 1989. Pola penerapan teknologi dalam peningkatan produksi dan 
pemerataan pembangunan. BPPTeknologi, Jakarta.

Lamusa, A., 2005.Faktor-Faktor Yang Mempengaruhi Produksi Kelapa Dalam Di Desa Labuan Lele Kecamatan Tawaeli Kabupaten Donggala. J.Agroland 12 (3) : 254-260

Pantjar Simatupang 2014. Pengembangan program bioindustri mendukung strategi induk pembangunan pertanian. |Informasi BBalitvet |Kamis, 06 Pebruari 2014)

Soebiapradja. 1991. kebijakan dan peranan pemerintah dalam penembangan kelapa di Indonesia. Makalah Seminar Ekonomi Perkelapaan. Batam, Riau 15 - 17 Januari 1991. 